\title{
The Evolving Structure of Civil Society and the State in Pakistan
}

\author{
MOHAMMAD QADEER
}

The 'Civil Society' is the newest factor in the development equation, and the strengthening of civil society is the latest addition to the agenda of development. This emphasis necessitates a probe into the structure of Pakistan's civil society.

The civil society in Pakistan-or anywhere else-has both the traditional and modern components. It is made up of institutions and organisations that stand between the state and the individuals as well as communities. They regulate the collective life at the intermediate level and act as mobilisers of people's opinions and actions. Pakistan's civil society is not entirely constituted by NGOs and special interest groups. It has both Beradaris, bazaar associations, and NGOs. The paper offers two conclusions: (1) Pakistans civil society has evolved through three phases and is divided in the traditional and modern tracks. In recent times, it has fractured along ethnic and sectarian lines and the denominational interests have come to dominate. (2) The state and the civil society evolve in tandem. Without an effective state, there can not be a strong and democratic civil society.

\section{Introduction}

The 'strengthening of civil society' is one of the newest items on the agenda of international agencies. The World Bank's 1997 annual report envisages an active role for civil society in the reconstruction of the state [The World Bank (1997)]. The bilateral aid agencies such as USAID, CIDA, etc., are generously funding non-governmental organisations (NGOs) ostensibly to strengthen civil society and promote good governance. The strategy of 'strengthening civil society' is an element of the new development paradigm. It is a component of a broad approach aimed at reorganising the state, expanding the scope of market and increasing people's participation in providing for their core collective goods [The World Bank (1997), pp. 2-3]. This new paradigm extends the domain of development planning to social institutions and organisations well beyond conventional concerns of economic development. It embraces social organisations, and political culture as objects of developmental policy and brings them within the purview of 'variables' to be manipulated. This paradigm has sparked the current intellectual interest in the study of 'civil society', both as an object and as a factor of development, namely, what it is and how it promotes development.

The current interest in the study of civil society is also driven by a political agenda. It is motivated by the Euro-American project to promote market institutions and non-governmental initiatives for the purpose of reducing the state's role in Eastern

Mohammad Qadeer is Professor, Urban and Regional Planning, Queen's University, Kingston, Canada. 
civil society be defined in the idiom of current (Western) democratic practice, or be viewed in a more universal vein as terrain for "private pursuits of public purposes" [Salaman and Anheir (1997), p. 60] is a question at the centre of present debate.

Norton maintains that democracy is not "contested elections and the secret ballot, but civil society where associations, clubs, guilds, syndicates, federations, unions, parties and groups come together to provide a buffer between state and citizen" [Norton (1995), p. 7]. In this sense, civil society is the mediating structure between the society and the state. It is not the whole society but those institutions in it whose primary function is to organise people's relationship with the state, in Ibrahim's words, "for collective participation in the public space between individual and the state" [Ibrahim (1995), p. 28].

In practice, civil society has come to mean NGOs, local communities, clubs, interest groups and other associational arrangements 'outside the sphere of state which ensure participation and empowerment of people in public affairs' [Elshtain (1997), p. 14]. It must be emphasised again that civil society does not include all social institutions of a society, but only those norms and organisations that express collective interests as well as action. The project of strengthening civil society is to build and sustain civic institutions outside the government, both for meeting collective needs and for holding the state accountable. This is how donor agencies and Western academics define civil society [McCarney et al. (1995)]. And they have co-opted Putman's concepts of social capital and civic culture to buttress their approach [Putman (1993)].

\section{THE CIVIL SOCIETY IN NON-WESTERN COUNTRIES: TWO VIEWS}

Most of the current formulations of civil society assume a secular society and industrial/post-industrial modes of production. They are premised on the prevalence of contractual transactions, interest-based social relations, and the separation of state, religion and economy. These formulations raise the methodological dilemma: whether to look for structures corresponding to Western civic institutions or to focus on indigenous organisations and institutions performing relevant functions for purposes of analysing civil societies in non-Western countries. Or, in other words, is civil society to be viewed in structural or functional terms?

A study of civil society in China classifies the two conceptions into political vs. sociological definitions-the political being the local surrogates of 'Anglo-American' liberal traditions of civil rights, representation and the rule of law [White et al. (1996), p. 4]. Sociological conceptions referring to (indigenous) social organisations "which are separate and enjoy some degree of autonomy from the state and are formed voluntarily by members of society to protect or extend their value" [White et al. (1996), p. 3]. I am inclined towards sociological or functional approach, defining civil society as (i) mediating structures between individuals and a state, (ii) which regulate and organise (some) collective action, and (iii) are counterweights to the state and market for purposes 
of accountability.

The structure of a civil society will change with social and economic development of a country. Also, the evolution of state will correspondingly realign institutions of a civil society. Thus, a civil society may be viewed as much a process as a structure.

Regarding Pakistan, Malik defines the civil society as aiming "to strengthen individual and collective rights and restrain authoritarianism" of both state and society implying "decentralisation, democratisation and debureaucratisation" [Malik (1997), p. 5]. While agreeing with the political goals of his definition, I am inclined to view civil society as institutions, organisations and practices-both traditional and modern-which define, influence and constrain a state's behaviour as well as serve as the organisational base for collective action at the intermediate levels of social life. This definition guides my analysis of Pakistan's civil society.

Pakistan's civil society is observable in formal institutions, such as political parties, labour unions, media and press, chambers of commerce, citizen clubs and community organisations as well as in traditional structures such as clans (Beradaris), village and neighbourhood organisations, traders associations, ethno-religious communities, religious orders, social networks, mores of social control and social (protest) movements. These are the 'mediating' structures that regulate, balance and influence the state, as well as organise collective action in public affairs. How they have evolved over time is the focus of the rest of this article.

\section{THREE PHASES OF CIVIL SOCIETY IN PAKISTAN}

Sociologically speaking, there was a precursor of civil society in the pre-British Pakistan (India). It was localised, made up of Beradaris (clans), Panchayats (village councils) and Jirgas, comprised of religious leaders, rural landlords and town notables.

These groups and organisations articulated, expressed and mobilised public opinion. They functioned as (local) community organisations and served as mediating institutions between individuals and the King.

British Colonial rule reduced the autonomy of these institutions and subordinated them fully to the state. The rulers became 'Mai-Bap' (parents) of the people. Yet the British rule also introduced corporate structures, formal institutions and codified legislative and administrative practices, thereby laying foundations of urban associations and organisations. The emergence of Muslim professionals and businessmen in cities led to the formation of a small 'modern' sector of civil society. The independence movement mobilised both the traditional and modern social organisations for prolonged civil disobedience against the colonial rulers. Thus by the time of independence (1947), broad contours of civil society had emerged and, even, norms and practices for holding the state in check had been forged.

From these roots, Pakistan's civil society has quickly evolved since 
independence. Its evolution since independence can be divided into three phases, each corresponding to a particular stage in the development of the state.

\section{Phase 1: Civil Society of Clans (Beradaris) and Welfare Associations 1947-1968}

Immediately after independence, the agenda of the Pakistani state was to consolidate the new country and reestablish peace and order disrupted by communal riots, partition and migrations. Public effort to draft a constitution and organise the government engendered competition for political and economic power among provincial, class and clan groups. Provincial leaders started agitating for fair share of political power in the proposed constitution and, later, for the economic parity of regions. The Muslim League, the party that spearheaded the independence movement, itself splintered into nine new parties [Waseem (1994), p. 114]. The Constituent Assembly elected from provincial legislatures, became the arena for bargaining among shifting coalition of politicians. This resulted in unstable governments-'six' different prime ministers in the first decade. The civil servants, who viewed themselves as the 'steel framework of state', and the army emerged as power brokers, in politician's fight for spoils.

A weak political order, increasingly alienated from citizens, dominated by civil servants and the army generals came to characterise the state. The civil society was largely limited to an oppositional role, with occasional cooptation of its emerging leaders into governance. In cities, it was centred around groups of lawyers, journalists, professionals and prominent families. Student associations gained some influence by periodically agitating against unpopular governmental policies. In villages and in tribal areas, clans led by rich landlords and hereditary chieftains were the base of civil society. This was particularly true of the erstwhile west Pakistan (post-1971 Pakistan) whose "politics...was by and large of a feudal nature" [Sayeed (1967), p. 87], despite ostensibly democratic state.

The most effective means of articulating and mobilising citizens' opinions and demands were public meetings and processions (demonstrations). The press, particularly Urdu language newspapers, was a potent instrument to the extent that it could arouse people's passions. The literary clubs, bar councils and college unions were the fora of urban intelligentsia. A few national associations, such as All Pakistan Women's Association (APWA), functioned as the élite's social clubs.

The seminal event of the first phase was the military coup and the establishment of General Ayab Khan's Martial Law regime in October 1958. The army rule reorganised the state. Army generals and civil servants stepped forward from behind the political curtain to establish 'a stable state'. Political parties were suppressed, press controlled and civil institutions muzzled. Though mosques and shrines have had a limited role in the civic discourse, the slogan of 'Islamic order' remained a potent 
symbol for rallying opposition to the government.

Ayab Khan held the view that "politically, our people are immature, they are in the process of emerging the tribal and feudal society" [quoted by Gauhar (1993), p. 190], therefore Pakistan has to have a system of government that 'suits the genius of its people'. He enacted Basic Democracies (1962), a tiered system of local councils, wherein people only voted for the union (village/neighbourhood) council. The rest were elected/nominated out by the lowest tier of councils. It was a "blending of democracy with discipline" [Gauhar (1993), p. 191]. Basic Democracies essentially reinforced the clan/beradari base of the civic society. Although Ayub's policies reinforced the traditional power structure, Pakistan's social structure was rapidly changing.

During Ayub's decade of development (1958-68), the economy of Pakistan began to rise from its agrarian moorings. The share of agriculture in GDP fell from 59.9 percent in 1949-50 to 46.1 percent in 1967-68. Shares of manufacturing, construction and services on national economy increased. Social disparities between the rich and the poor sharpened. East and West Pakistan diverged in terms of economic development. Pakistan's cities exploded and in central Punjab urban ways of life began to penetrate villages. A new consciousness about people's social and economic rights began to sweep the country. Ayub's iron rule only dammed the feeling of disenfranchisement. The narrowly won indirect Presidential election (1964) and an inconclusive war with India undid Ayub's controlled democracy. Civil society roared to action through marches, strikes and mammoth public meetings, thereby bringing an end to Ayub's era.

The social organisation of civil society towards the end of Phase 1 had changed on the surface. Basic democrats and union councillors had been nurtured as a new class for local leader, while army generals, landlords and a coterie of civil servants formed the ruling élite [Burki (1971)]. Yet most of the new leaders melted away with the disappearance of the State's patronage. Though a politically motivated attempt to foster a middle stratum of local leaders failed, new interests and social classes in the form of traders, industrial bourgoisie and urban professionals and labour had taken root. The anti-Ayub agitation, emboldened by Zulfiqar Bhutto's challenge to his authority, exploded on account of these contradictions of interests and values in the social structure. It marks a threshold point in the evolution of Pakistan's civil society, engendering many long-lasting changes.

First, the anti-Ayub movement re-established public meetings, marches and mass action as instruments of articulating and mobilising public concerns. Second, it brought out cleavages within social classes. The most striking example was agitation by engineers, doctors, accountants and other 'technocrats' in public bureaucracy against the reigning Civil Service of Pakistan (CSP). It was a new phenomenon to witness Class I officers marching to demand parity with other officers. The civil society began to be splintered along occupational, ideological, provincial, ethnic and traditional vs. modern lines. It could be mobilised for concerted action in short bursts to confront a discredited 
government, but had little capacity to act autonomously.

The mass agitation against Ayub, unlike the previous demonstrations, spread to small towns bringing down "Ayub's Basic Democracies and his elaborate facade of indirect elections" [Gauhar (1994), p. 433]. By 27th March 1969, Ayub was gone and with him tumbled his guided democracy and his deliberately crafted state, overwhelmed by Pakistan's civil society.

The following findings sum up the structure of civil society at the end of Phase 1:

(i) The civil society evolved with the changing economic organisation and societal structure, as well as in response to the emergence of the centralised and authoritarian state.

(ii) The emergence of a military-backed regime and the centralised state reduced the scope for collective action by the civil society.

(iii) A multifocal structure of the civil society emerged, realigning organisations and institutions into modern-urban versus traditional-rural sectors on a broad plane and within it into ethnic, religious or occupational social formations. The civil society evolved from a relatively cohesive clan-based social organisation into social formations based on ethnicity and class interests, as well as primordial ties.

(iv) Yet various segments of civil society showed the capacity to act together through mass protests in desperate attempts to hold the government accountable.

(v) The mass protests turned out to be the ultimate check on the authority of the State.

\section{Phase 2: Ideological State and the Divided Civil Society, 1969-1988}

The second phase in the evolution of Pakistan's civil society spans the period of three divergent regimes, namely General Yahya's inter-regenum (1969-71), Zulfiqar Bhutto's Pakistan Peoples Party (PPP) government (1972-77) and General Zia's rule (1977-88). Yet from our perspective, this period has a thematic unity. In different ways all three regimes focussed on channelling public expression, preempting the possibilities of mass movements and neutralising the scope of civil society. Thus, containment of civil society is the defining feature of this period. Bhutto and Zia explicitly sought to 'reconstruct' the State along preferred ideological lines. All in all, civil society was subject to similar pressures and reconstructive thrusts during the period of three regimes. These processes lent a unity to this period.

After Ayub's downfall, an election as a means of legitimising governments came to be the political norm. General Yahya had to hold national elections within a year of succeeding Ayub. Zulfiqar Bhutto drew his populist authority from the 1970 elections and, eventually, was brought down by the discontent sparked by his cynical attempts to 
manipulate the 1977 elections. General Zia consolidated his rule with the promise 'to hold elections in 90 days' and stayed on 11 years justifying his tenure on the basis of, initially, a referendum and, subsequently, with various forms of guided elections and presumed mandate for Islamic rule. Elections could be manipulated but they could not be dispensed with.

In this phase, ethnicity based on linguistic and regional (provincial) ties, emerged full blown as one of the organising principles of civil society. Pakistan's public opinion came to be explicitly refracted through the lens of ethnicity, earlier expressed in East and West Pakistan's constitutional deadlock which eventually lead to the separation of East Pakistan (1971). Undoubtedly ethnicity as an element of political culture has always been present, yet from 1970 it came to be a critical element in the organisation of the state and society.

Bhutto relied on his populist and socialist slogans either to go around or to co-opt ethnic leaders in his rule. Yet his regime was continually at odds with Pakhtoons, Balochs and Muhajirs. General Zia's 'Islamic order' also could not neutralise ethnicity's potential for social mobilisation.

The volcanic events of 1971 shook the power structure in Pakistan. Bhutto's Manifesto of "Islam and Socialism" strengthened two divergent classes. His populist socialist ideology vented peasant, worker and student demands, yet paradoxically his Islamic blandishments and the nationalist policies invigorated conservative mullahs, landlords and Bazaars factions. The emphasis on indigenous dress, and regional languages made folk leaders and party workers feel at home in portals of power and authority, on the one hand, and legitimised leadership of Islamists (mallahs) and small town merchants, on the other.

Bhutto's policies of expanding the state's role in economic, educational and cultural spheres, through nationalisation of industries, schools, colleges, etc., eroded the institutional base of the modern component of civil society. Leading industrialists were ousted. Professors, writers and opinion leaders were turned into public servants, as private schools/colleges and cultural associations were nationalised. Similarly, nationalisation of major industrial establishments brought labour unions and professional associations under the State's control. These policies reduced the autonomy of 'mediating' structures, particularly professional associations, student and labour unions, and the press.

Bhutto relied on landlords for political alliances, thereby reinforcing their power in rural areas, despite his claims to be Quaid-i-Awam (people's leader). The reduction of big industrialists' role unwittingly left the market free for informal sector bazaaris, who operated largely outside the net of taxes and other state controls. Also the mosque as a forum for public expression and social mobilisation could not be controlled by the State. Thus, landlords, traders, workshop owners and preachers gained influence, at sufferance of urban professionals, commercial and industrial interests, and urban labour. 
The centre of gravity in the civil society tilted towards institutions and groups whose primordial ties and modes of operations protected them from the State's intrusions. Another mass protest, sparked by an alliance of opposition parties (Pakistan National Alliance-PNA), for promoting 'Nizam-i-Mustafa (Prophet's order) brought Bhutto's regime to an end. General Zia's coup disposed his rule (1977). PNA movement drew its strength from small towns, the bazaar sector and mosques. The Civil Society once again, showed its capacity to bring down an overextended state, yet not able to reform it to sustain its democratic thrusts.

Zia's coup had the support of PNA. It represented a new alignment of social groups constituting conservative segments of various social classes. It linked the traditional parts of middle and upper classes with the military-landlord ruling strata. The new urban bourgeoisie, made up of bazaar traders, Islamists and revived industrialists joined forces with the military-bureaucratic élite. Landlords quickly joined the new power structure as has been their practice. Some resistance was offered by People Party workers, women's groups, liberal intellectuals, and other social groups energised by the People's Party. Yet public flogging, mass arrests, muzzled press and emasculated judiary, under martial law regulations and Hadood (Islamic) laws, contained this resistance. Mosques, seminaries and the Islamic press gained influence in the Zia's regime. Malik observes that "under General Zia-ul-Haq, in particular, Pakistan suffered the most suffocating years of its existence and, in the wake of depoliticisation, regimented ideas like Chaadar and Chardiwari denoted women's place in the home, democracy was portrayed as an anathema to Islam and media was made use to silence the opposition" [Malik (1996), p. 94]. Thus the Islamic faction of civil society gained at the cost of secular, modern and urban interests. This reordering of civil society helped sustain the Zia regime for 11 years.

In Zia's period, the migration of young male from villages to cities and from Pakistan to the Middle East and Europe/North America reached its peak, though Bhutto had initiated policies for labour export. The accelerated social mobility served both as a safety value for discontented working and middle classes and as a means to direct people's energies to a non-political channels. The Afghan crisis, with its flow western and Saudi funds and arms to Pakistan's army (and intelligence agencies) turned out to be another transforming factor for the social structure and civil society. Aid for Afghan fighters and refugees was channelled by the Army, through Islamic groups whose seminaries became the training ground of armed and indoctrinated Islamic youth. They eventually have grown into a potent force in the contest for street power, further splintering Pakistani society into sectarian, ethnic and ideological fragments. These primordial social formations were not new, but they gradually come to dominate civil society.

Although Pakistanis have consistently voted against conservative Islamic parties in all elections, street power and communal appeal of religious organisations give them 
a greater influence in public affairs. The persecution of minorities, repression of women, and muzzling of secular discourse are now openly advocated and argued for in public fora.

Ethnicity and denominationalism have proven to be the primary bulwarks against the overbearing State. They are increasingly the basis for organising collective action and community initiatives.

By the end of Phase 2, civil society and political culture have been dyed in sectarian, ethnic and ideological colours. The ideological state split open the civil society and brought the ethnic and sectarian formations to the forefront.

To sum up the changes in civic society during Phase 2 , the following is a brief recapitulation of points discussed above.

(a) 1971-88 was largely a period of an ideological state, though of two different ideologies.

(b) The ideological state sustained and, eventually, contributed to the fall of both Bhutto and Zia's rule.

(c) Civil society came to be organised along ethnic and sectarian lines, submerging the rural versus urban and traditional versus modern divides. Almost every institution has splintered into ethnic and sectarian factions on the one hand, and social class and ideological interests on the other.

(e) The role of mosques, seminaries, bazaar sector and small towns in public discourse and society increased. Urban institutions and secular associations lost ground in this period. The balance of power shifted towards conservative groups and traditional values within civil society.

(f) Civil society retained its capacity to oust or shake a discredited regime through mass protests but it was too fragmented to promote an active democratic order.

(g) It could act in unison through mass protests for short periods in reaction to the state's policies.

\section{Phase 3: Fractured State and the Denominational Civil Society, 1988-1997}

On the blazing afternoon of August 17, 1988 President (General) Zia's plane blew up over the desert town of Bahawalpur bringing a fiery end to 11 years of the military rule. The tragedy of this afternoon gave an opening to the civil society.

Gen. Zia's military government had long lost its legitimacy and credibility. It was hobbled by popular protests organised by the Movement for Restoration of Democracy (MRD), an alliance of revived political parties. Its assumed mandate had expired with the dismissal of hand-picked Junejo's ministry. Free elections based on political parties became a preferred alternative once again.

The 1980s witnessed transformative changes in Pakistan's economy and society. Compared to 1970 s (mostly Bhutto's period), the economic development 
accelerated. GDP at constant factors increased at an average annual rate of 6.45 percent in 1980s rising from 4.84 percent in the 1970s. Manufacturing increased at the rate 8.29 percent per year on the average, and even agriculture charted a growth rate of 5.44 percent, recapitulating the momentum of Green Revolution days. The per capita income increased, in Zia's period, from $\$ 230$ (1977) to $\$ 350$ (1988) in constant terms at the mean rate of 4.72 percent per year. Informal and black economies are not counted in these figures which together are estimated to have ranged between 47 to 67 percent of annual GDP in this period [Iqbal and Qureshi (1996), Table p. 9]. Obviously economic growth affected the class structure and realigned communities and interest groups within classes.

1988-97 is a period of democratic revival. Four national elections have been held, 1988, 1990, 1993 and 1997, to resolve recurrent crises of governance arising from pervasive corruption, mismanagement and ethnic and sectarian violence. The army has played the role of king-maker and arbiter of political power, yet it has been inhibited from assuming the reins of government. A two-party system, the Pakistan Muslim League (PML) and PPP, centred around two personalities, Nawaz Sharif and Benazir Bhutto, has emerged. Each has alternated in forming government and ousted by armybacked presidential decrees prompted by popular discontent. Judiciary has asserted its independence. The press is free though subject to economic pressures. Labour unions, student associations, and chambers of commerce are divided into ethnic, ideological and political factions. Rather than functioning as intermediate institutions of governance, these associations have turned into what for China White describes as "channels of privileged access to the state's agencies for their members" [White et al. (1996), p. 17]. They have turned into lobby groups for partisan-interest.

In Phase 3, the Pakistan state has been losing its hold on society. First, the corruption and mismanagement of both the PML and PPP governments have eroded the moral and legal authority of the State. Second, the fiscal crisis of the State, mounting public debt, increasing budgetary deficit, and spiralling inflation has further rendered the State incapable of meeting people's basic needs. The politics of confrontation, combined with PLM and PPP's need to form parliamentary coalitions, have invested splinter groups and sectarian parties with undue influence. Finally, rising crime, unresolved ethnic and regional disaffection and sectarian violence have eroded the authority of the State. All in all, the internal contradictions and the corruption of the State have reduced its effectiveness and credibility. Its writ runs sporadically in many parts of the country.

Karachi, the premier city of the country, has been besieged by Muhajir violence for more than 10 years. Jhang District in Punjab has witnessed long spells of sectarian riots for years. A mullah-led rebellion in Swat and Malakand district won the right of Shariat (Islamic) law rule for the area. The dacoits (Brigands) have free run in many districts of the Sindh province.

All in all, the State has fractured into partisan governments and self-serving 
cliques. The fracturing of the State has led to the ascendancy of sectarian, ethnic and clan-kinship organisations at local and regional levels, resulting in the fragmentation of civil society.

Civil society has long operated on two tracks. One the urban and modern, which is visible in conferences, seminars and meetings of NGOs, bar councils, professional associations and literary clubs. The organisations operating in this track espouse modern liberal values, e.g., international human rights, freedom of expression, independent judiciary, etc., and they expect the public authority to enforce their demands. Chambers of commerce and industries are a part of this track. They are one segment of the modern track that has considerable influence over the government's policies.

The second track of civil society is made up of ethnic, denominational, sectarian and clan organisations that espouse traditional religious values. This track is made up of mosques, seminaries, Islamic/ethnic/territorial segments of student and labour unions, Bazaar traders and small town industrialists. The Urdu press is its forum and public meetings, marches, protests, and occasional violence are its instruments. Parts of the apparently 'modern' institutions also operate in this track, for example, sections of bar councils, traders and professional associations, universities and the Shariat (Islamic) courts.

The modern track has been blocked by the ideological state and military regimes. It takes only a touch of censorship, banning of meetings and visits by secret police to block this track, whereas the primordial ties and the traditional base of the ethnoreligious segments protect them from the State's interventions.

The NGOs largely operate in the modern track, though there are large numbers of traditional community organisations for social service and charitable works. Secular NGOs are not a match for the denominational and ethnic organisations in civil society. They may be effective in initiating local development or carry out welfare activities, but they have limited 'street power' and poor capacity to mobilise people.

Though divided among themselves, the ethnic and denominational elements of civil society have come to be its 'primary' agents in 1988-1997. The denominationalisation of civil society has produced glaring contradictions of values and norms. A few examples below illustrate this point. Elections have been widely accepted as means of choosing national governments. Yet, 'personality cult' and ethnic loyalties are bases of political parties. The English press and the Urdu journalism reflect contrasting public philosophies and modes of discourse. 'Jang' and 'News' as well as 'Nation' and 'Nawa-i-Waqt' are paired English/Urdu newspapers from the same publishing houses. English newspapers of these houses have a modernist and democratic slant and a calm voice, while their Urdu counterparts rely on conspiracy theories, the idiom of besieged Islam, and the personality cult in interpreting national events. The leader of the Pakistan Movement for Justice promises to publicly hang about 200 corrupt politicians and officials to reform the country. The chairperson of Human Rights 
Commission, Asma Jahangir, is openly threatened of death for sheltering a young woman from her father's wrath and defending in court a Christian child accused of 'insulting the holy prophet'. While NGOs and public agencies hold seminars, produce papers and organise 'walks' for human rights, democracy and environment, whole districts and cities are ruled by armed clans, Mullahs (priests) and ethnic gangs. As Khalid Ahmed, a veteran journalist observes: "The grassroot politics is different from electoral politics.....daily life influenced by violent activism.....the real power in Pakistan lies with religious groups" [The Friday Times, Lahore (1996)].

The following points recapitulate observations about the evolution of civil society in Phase 3.

(a) In the third phase (1988-present) civil society has titled towards ethnic, denominational and sectarian organisations.

(b) The dualisation of civil society into the 'modern-liberal' versus 'religiousethnic-traditional' tracks, and within each track the emergence of competing social organisations has reduced its cohesiveness. Practically, there is not one but many civil societies, yet denominational organisations are beginning to dominate.

(c) Elections as the means of changing and legitimising a government have been entrenched in the political culture. However, their outcomes are increasingly influenced by public discontent and mass protests.

(d) The State has increasingly become ineffective and (more) vulnerable to the pressures of groups capable of mobilising street protests.

(e) Public meetings, demonstrations and violence, threatened or real, have been institutionalised as instruments of the denominational civil society.

\section{Civil Society, Community Development and Collective Goods}

Civil society has two broad functions, namely: (i) to articulate people's opinions and expectations and organise them for participation in public affairs; and (ii) to mobilise communities for the provision of collective goods, particularly at local and regional levels. Like most of the current literature, I have also concentrated on the first function, namely on civil society's role as the 'mediating' institution between individuals and the State. The second function, namely community organisation for the provision of collective goods, has not been analysed. In this section, this role of civil society will be briefly discussed.

Traditional civil society, dominant in Phase 1, had institutionalised its function of providing collective goods in the form of charity, mutual help and community action. Typically, a clan (beradari), village or neighbourhood had formal and informal ways to look after its needs. Mosques, for example, were built and maintained by charitable individuals or local communities. Similarly, schools, orphanages, youth (sports) clubs 
were established as charitable and social welfare activities. In rural areas, paths, drains, streets or flood control levees were built through periodic mobilisation of community work details, usually of the lower caste peasants.

In cities and towns, Muslim associations (e.g., Anjuman-I-Jamayat-Islam) were formed to build schools, colleges and dispensaries. At the national level, there were organisations promoting particular interests or providing specific welfare services, e.g. all Pakistan Women Association (APWA), Pakistan Family Planning Associations and the Red Cross Society. All in all, community organisation for the provision of collective goods has been an institutionalised practice in rural as well as urban areas.

By the late 1950s, community development was included in the national Five Year Plans, first taking the form of Village Agriculture and Industrial Development (VAID) programme, whose merger with Ayub's Basic Democracies turned it into a tool of patronage. It was resurrected as Integrated Rural Development Programme (IRDP) and People's Work Programme in the 1970s, and absorbed into the Rural Works and (Local) Councillors' and Legislators' Matching Grant Programme in the 1980s, which were eventually rechristened as Tamir-I-Watan and Social Action Programmes (SAP) of the 1990s. Local development was the ostensible purpose of various mutations of community development sponsored by the government. Yet the State's supervision politicised and corrupted the process of community organisation.

Phase 2, the dualisation and division of civil society into ethnic, sectarian or class segments has pitched them against each other. Instead of collective goods for a local community, schools, mosques and other public institutions are being developed predominately for particular sectarian, clan or class groups, so much so that even student associations in General Zia's period began to be organised along clan/caste ideological or sectarian lines. A university may, for example, have separate organisations for Sindhi or Muhajir students, or for Gujjars or Al-Hadith from, say Toba Tek Singh district. Cumulatively the State's sponsorship of the community development and the fragmentation of civil society have eroded the institutional base for common action.

In the 1980s, religious and sectarian organisations were at the forefront of developing mosques, seminaries, welfare societies for their respective groups and communities. This network of denominational institutions is now a dominant part of local collective goods, particularly in rural areas. Much of this network has been developéd and sustained from public funds (Zakat), foreign assistance and individual charity. The State has played a critical role in fostering particular segments of civil society.

The 1980s have also witnessed the emergence of special purpose and interestbased NGOs in the modern-urban track. The availability of public grants and international aid has fostered the NGO movement. From a few hundred in the early 1980s, the number of registered NGOs increased to 8,500 by 1991 [EUAD (1991), p. 101]. The majority of these NGOs aims at providing welfare services for local 
communities; 6,500 were registered with the Social Welfare Ministry in 1991. Yet many are national affiliates of International NGOs, e.g., South Asia Partnership, CARE Pakistan, Aga Khan Foundation. A few have been effective in promoting the process of local and regional development and gained international recognition for their work, e.g., Edhi Foundation, Aga Khan Rural Support Programme (AKRSP), Orangi Pilot Project (OPP), The World Conservation Union (ICUN). The Human Rights Commission has been on the forefront of protecting rights of women and minorities, but it struggles as much against the government as against the denominational and traditional components of the civil society. All in all, NGOs in general are viewed skeptically. Their high salaried executives, advocacy of donors' agenda and lavish foreign as well as public funds have affected their credibility. Even a federal minister of population recently commented that "most of NGOs, with few exceptions, were busy minting money from donors" [The Nation Net (1997)].

An overall evaluation of the NGOs' effectiveness as providers of collective goods is beyond the scope of this paper. Yet even successful NGOs (i.e., OPP, AKRSP, etc.) have remained confined to a particular area or community. Their effectiveness has not sparked a replication in other areas or fostered any social movements.

From the perspective of civil society, NGOs are functioning as conduits and contractors for national and international development programmes. They have not yet evolved into social institutions for mobilising people and organising collective action.

To conclude the analysis of civil society's role in the provision of collective goods, three patterns are observable.

(i) Pakistan's civil society has evolved a wide network of community organisations.

(ii) The State's attempt to promote and guide community development and subsequently to foster supportive local institutions has resulted in politicisation and sectionalisation of local (voluntary) initiatives.

(iii) The emergence of fragmented and denominational civil society has further eroded the basis of social contract between people and the State. Social mobilisation as a function has been split, by and large, along ethnic and sectarian lines within local communities. There is a lot of community action, but most of it is targeted for the welfare of local groups and special interests. Charity is plentiful but organised collective action is scarce.

\section{INTERPRETATIONS AND CONCLUSIONS}

\section{The Structure of Civil Society}

Pakistan has been described as an unstable, failed or (politically) undeveloped state [Ziring (1975) and Ali (1983)]. It has earned these appellations on account of the 
frequent changes of its elected governments and long spells of military rule. In its 50 years of independence, Pakistan has had 19 prime ministers, including four appointed for interim periods and two serving twice, 24 years of military rule, as well as three constitutions. Since 1986, no elected government has completed its term, all were removed midway on charges of corruption and ineffectiveness. Is this instability of the government primarily a failure of what Malik calls "élitist bureaucrats, arrogant generals, opportunist feudalists, bigoted mullahs" [Malik (1996), p. 259]. Or is it a symptom of a more pervasive malaise; namely a weak civil society. This question underlies our inquiry.

For many Western scholars, Pakistan's instability is not surprising. They maintain that Muslim societies have a 'feeble yearning of civil society' [Gellner (1991), p. 506] and are deficient in political culture and social institutions that sustain democratic ethos and citizenship.

This point of view is not supported by the evidence presented in the present article. Pakistan's civil society and state have evolved in tandem. Civil society has played a significant role in the structure of governance. This conclusion, of course, is based on a more generic and less Euro-centric definition of civil society.

Generically, the term civil society refers to social institutions and organisations constituting the middle ground between a society and state. It consists of social norms, conventions, modes of public opinion formation, political practices and organisations which define citizens rights, responsibilities and acts as a check on the state. In analysing the civil society of Pakistan. I have identified and examined social organisations which perform the functions of intermediate or mediating institutions between the state and the individual as well as the society.

This functional approach has revealed that civil society is made up of clans, village councils, community groups, associations, NGOs-a divergent congeries of social organisations. These groups and organisations differ in their purpose, values and approach. They can be classified in two broad tracks, namely, traditional-rural versus modern-urban in terms of their mode of operation; and within each tract they can be differentiated by their social structure into ethnic, sectarian, class and interest-based organisations. Overall, Pakistan's civil society has evolved from a network of clans and (welfare) associations in the 1950s and 1960s to a constellation of socially fragmented groups and organisations in 1970s and 1980s. Currently the denominational organisations have come to dominate civil society, with common good and public interests being defined by folk-religious and ethnic interests. This conclusion is echoed in the following quote from a newspaper. "In terms of influencing the civil society, the only funded non-governmental, non-profit organisations which exercise considerable control over peoples' behaviour and mobilise communities for their causes are (seminaries) Madarissas" [Mushtaq (1997)].

Within civil society, the power balance has tilted, with acts of omission and 
commission of the state, towards, ethnic and denominational organisations, to the disadvantage of the modern-secular organisations. This trend is visible in both roles of civil society, namely, (i) holding the state in balance and accountable, and (ii) providing (local) collective goods through community organisation. Little by little, the denominational civil society is weakening the state.

Pakistan's civil society has been very vigorous. Three entrenched governments were overthrown by mass protests and which, in one case, escalated into an armed rebellion. The threat of mass discontent and civil disobedience have haunted all governments since the fall of Ayub's regime. This apprehension has structured the state in Pakistan since then.

Another manifestation of civil society's strength is the institutionalisation of elections as a means of resolving the state's recurrent crises and legitimising governments, including military rules. Ayub, Yahya and Zia, all military generals, had to eventually justify their mandate with direct or indirect elections. Presently, elections have become the ultimate arbiters of stalemated battles between Benazir Bhutto and Nawaz Sharif. These are indicators of Pakistan's civil society's role in governance.

\section{The State and Civil Society}

Pakistan's civil society has largely operated in the reactive mode. It is energised periodically to react to the state's excesses and dispose-off corrupt and ineffective governments. For short durations, its divergent groups and components come together to confront a regime that becomes too self-serving and/or unresponsive. Yet in-between these reactive outbursts, civil society remains shadowed by the State. Its weak institutional base is partially the result of its social organisation. The following conclusions emerge from the analysis of relationship between the State and civil society in Pakistan.

(i) Pakistan's civil society and the State have swung from 'strong state, weak society' to 'weak state, strong society' and back periodically. Its evolution refutes the neo-orientalist notion that Muslim societies fall in one or the other category, and their essential core is immune to change-a finding supportive of Sadowski's observation [Sadowski (1993)].

(ii) Positing zero-sum relations between the State and civil society is not supported by Pakistan's experience. Its civil society is autonomous, whose foundations lie in the traditional social structure and whose evolution is shaped by state policies and social and economic development.

(iii) For modernising and reconstructing civil society, a responsive State and a good government are essential. Rebuilding and sustaining an effective and just State is necessary for institutionalising a progressive civil society. Even enthusiasts of civil society like Soros, are beginning to acknowledge this proposition [Soros (1997)]. Pakistan's example affirms it. 


\section{Pakistan's Development and its Civil Society}

The social and economic development of Pakistan requires extensive institutional reforms, i.e., rule-based transactions, transparency, impersonalisation of public dealings, enforcement of laws and regulations, community cohesiveness and progressive values. Civil society is divided into clan, ethnic and denominational communities. In its present state, it has limited capacity for institutional reform and sustained development. Pakistan's agenda for the strengthening of civil society should aim at reconstituting communities on a non-partisan basis and redefining the scope for collective action. This agenda requires both a strong State and a strong civil society of humanistic values. Without a reformed state, civil society holds little promise of promoting development. A reformed state is also necessary to restructure civil society. The agenda of development should be based on a parallel realignment of the State and civil society.

\section{Unspoken Civil Society}

There is another level of civil society that is seldom discussed in international discourse on this topic. It is not the State as an abstraction, but public functionaries and policies and procedures that confront an individual. It is the proverbial common person's experiences in daily dealings with public agencies and officials that concretises civil society for him/her. The bribes and influence peddling required in obtaining entitlements and rights as a citizen are of primary concern at that level. How a police inspector can lock up a person arbitrarily with impunity! How a Patwari (petty land revenue official) squeeze poor farmers! How it requires connections, even to pay utility bills! How public schools and hospitals fail to provide education and health! These are examples of citizen's entitlements that the State in Pakistan fails to deliver. These entitlements also constitute the civil society of daily life. Yet the World Bank and global policy forums are occupied with democracy movements, non-governmental initiatives, and market reforms in their project to strengthen civil society.

This focus on political system and ideological agendas ignores a significant part of civil society as it affects people's daily life. The present article has also neglected this 'unspoken' civil society, as it has been conceived essentially as an argument in the current discourse.

Civil society of daily life is directly related to the administrative structure of a state and social relations of a society. In contemporary mass societies an efficient, fair, accountable and professional (protected from political interference) bureaucracy is essential to sustain an effective civil society. Pakistan's administrative system has gradually become both incompetent and corrupt. It needs to be rebureaucratised for fair and efficient public service, and not debureaucratised, to strengthen the civil society. It may also be the case for many other countries. 


\section{REFERENCES}

Alavi, Hamza (1980) Pakistan and Islam: Ethnicity and Ideology. In Fred Halliday and Hamza Alavi (eds) State and Ideology in the Middle East and Pakistan. London: Macmillan.

Ali, Tariq (1983) Can Pakistan Survive: The Death of a State? Hamondsworth: Penguin. Burki, Shahid J. (1971) Interest Group Involvement in West Pakistan's Rural Works Programme. Public Policy 19: Winter.

Cohen, Jean, and Andrew Arato (1992) Civil Society and Political Theory. Cambridge, MA: The MIT Press.

Environment and Urban Affairs Division (EUAD) (1991) The Pakistan National Conservation Strategy. Karachi: Government of Pakistan, The World Conservation Union. Gauhar, Altaf (1993) Ayub Khan: Pakistan's First Military Ruler. Lahore: Sang-e-Meel Publications.

Gellner, Ernest (1991) Civil Society in Historical Context. International Social Science Journal 129: (August) p. 91.

Ibrahim, Saad E. (1995) Civil Society and Prospects of Democratisation in Arab World. In Andrew R. Norton (ed) Civil Society in the Middle East. Leiden: E. J. Brill. Iqbal, Zafar, and Sarfraz K. Qureshi (1996) The Underground Economy in Pakistan: Fresh Estimates, 1972-96. Pakistan Institute of Development Economics, Islamabad. (Research Report.)

Malik, Iftikhar (1997) State and Civil Society in Pakistan. London: Macmillan Press. Mamdani, Mahmood (1996) Citizen and Subject. Princeton: Princeton University Press. McCarney, Patricia, Halfani, Mohamed et al. (1995) Towards an Understanding of Governance: The Emergence of an Idea and Its Implications for Urban Research in Development Countries. In R. Stren and J. K. Bell (eds) Perspectives on the City 4. Toronto: Centre for Urban and Community Studies, University of Toronto.

Mushtaq, Najam (1997) The News Internet http//www. Jang-Group.com/the news/index.html Nov 12/7.

Myrdal, Gunnar (1968) Asian Drama. New York: Pantheon.

Norton, Augustus R. (1995) Civil Society in the Middle East. Leinden: E. J. Brill.

Putman, Robert (1993) Making Democracy Work. Princeton: Princeton University Press. Sadowski, Yahya (1993) The New Orientalism and the Democracy Debate. Middle East Report. July/Aug, No. 18.

Salamon, Lester, and Helmut Anheier (1997) The Civil Society Sector. Society. Jan/Feb 97.

Sayeed, Khalid B. (1967) The Political System of Pakistan. Boston: Houghton Mifflin. Soros, George (1997) The Capitalist Threat. The Atlantic Monthly. Feb.

The Nation Net (1997) http://www.brai.net.pk/nation.html May 24/7.

The World Bank (1977) World Development Report 1977. New York: Oxford University Press. 
Waseem, Mohammad (1994) Politics and the State of Pakistan. Islamabad: National Institute of Historical and Cultural Research.

White, Gordon, Jude Howell, and Shang Xiaoyuan (1996) In Search of Civil Society. Market Reform and Social Change in Contemporary China. Oxford: Clarendon Press.

Ziring, Lawrence (1975) Perennial Militarism: An Interpretation of Political Undevelopment. In W. H. Wriggins (ed) Pakistan in Transition. Islamabad: University of Islamabad Press. 